\title{
Subtype 2 of Angiotensin II Receptors Controls Pressure-Natriuresis in Rats
}

\author{
Ming Lo, Kiao-Ling Liu, Pierre Lantelme, and Jean Sassard \\ Département de Physiologie et Pharmacologie Clinique, Centre National de la Recherche Scientifique, URA 1483, \\ Faculté de Pharmacie, 69373 Lyon Cedex 08, France
}

\begin{abstract}
Angiotensin II recognizes two receptor subtypes, $\mathbf{A T}_{1}$ and $\mathbf{A T}_{2}$, both of them having been recently cloned. Although $\mathrm{AT}_{2}$ receptors represent 5-10\% of angiotensin II receptors in the kidneys of adult rats, their function remains unknown. In the present work, we examined the possible contribution of $\mathrm{AT}_{2}$ receptors to the regulation of pressurenatriuresis in anesthetized rats infused either with the specific $A_{2}$ antagonist PD 123319, or with CGP 42112B, an $\mathbf{A T}_{2}$ ligand with agonistic properties. The effects of $\mathbf{P D}$ 123319 were examined in a preparation with stable levels of angiotensin II, and in which $\mathrm{AT}_{1}$ receptors were blocked by the specific antagonist losartan. The effects of CGP 42112B were studied in rats deprived of endogenous angiotensin II. $\mathbf{A T}_{2}$ receptor blockade with PD 123319 did not change the renal blood flow while it increased the diuresis and natriuresis. These effects persisted even after full $\mathrm{AT}_{1}$ receptor blockade with losartan. CGP 42112B did not modify the renal blood flow, but dose-dependently decreased urine flow and natriuresis. These results show that, contrary to $\mathrm{AT}_{\mathbf{1}}$ receptors, renal $\mathrm{AT}_{\mathbf{2}}$ receptors have no effect on total renal blood flow, but blunt the pressure-natriuresis, thus demonstrating that this receptor subtype is involved in a function of importance for body fluid and blood pressure regulation. (J. Clin. Invest. 1995. 95:1394-1397.) Key words: renin-angiotensin system • renal perfusion pressure • renal blood flow $\cdot$ glomerular filtration rate $\cdot$ sodium excretion
\end{abstract}

\section{Introduction}

One of the most important effects of the renin-angiotensin system is to influence renal functions through the vasoconstrictor and anti-natriuretic properties of angiotensin II $(1,2)$. As a consequence, either acutely (3) or chronically (4), angiotensin II shifts to the right the pressure-natriuresis relationship

Part of these results was presented as an oral communication at the 15th Scientific Meeting of the International Society of Hypertension, March, 1994, Melbourne, Australia.

Address correspondence to Dr. Jean Sassard, Département de Physiologie et Pharmacologie Clinique, Faculté de Pharmacie, 8, avenue Rockefeller, 69373 Lyon Cedex 08, France. Phone: 787770 86; Fax: 78777118.

Received for publication 13 September 1994 and in revised form 14 December 1994.

J. Clin. Invest.

(C) The American Society for Clinical Investigation, Inc.

0021-9738/95/03/1394/04 \$2.00

Volume 95, March 1995, 1394-1397 which is of utmost importance in the long-term control of blood pressure (5). Binding experiments demonstrated that angiotensin II recognizes two receptor subtypes (6), $\mathrm{AT}_{1}$ and $\mathrm{AT}_{2}{ }^{1}$ both of them having been recently cloned (7-10). Although $\mathrm{AT}_{2}$ receptors represent 5 to $10 \%$ of angiotensin II receptors in the kidneys of adult rats $(11,12)$, their function remains unknown as all the so far studied effects of angiotensin II are blocked by $\mathrm{AT}_{1}$ receptor antagonists (13-15). The aim of the present work was to examine the possible contribution of $\mathrm{AT}_{2}$ receptors to the regulation of pressure-natriuresis in rats.

\section{Methods}

Animals. 10-wk-old male Sprague-Dawley rats (Iffa-Credo, Les Oncins, France) were used in these studies. The rats were allowed at least $1 \mathrm{wk}$ to acclimatize to our laboratory, and were housed in controlled conditions (temperature: $21 \pm 1^{\circ} \mathrm{C}$; humidity: $60 \pm 10 \%$; lighting: $8-20 \mathrm{~h}$ ). They were fed a standard rat chow containing $0.3 \% \mathrm{NaCl}$ (Elevage UAR, Villemoisson sur Orge, France) and tap water ad libitum.

Surgical preparation. Pressure-natriuresis was studied using the method of Roman and Cowley (16). The right kidney and adrenal gland were removed and the rats allowed 7-10 $d$ to recover. On the day of experiment, the rats were anesthetized with Inactin $(100 \mathrm{mg} / \mathrm{kg}$, i.p., Byk-Gulden, Constance, Germany) and placed on a heating blanket (Model 50-6980; Harvard Apparatus, Edenbrige, KY) to maintain the rectal temperature at $37 \pm 0.5^{\circ} \mathrm{C}$. After tracheostomy, the left jugular vein was cannulated for infusion. Catheters were placed into the left carotid and femoral arteries to sample blood and to record the mean arterial blood pressure through a pressure transducer (Model P23ID; Statham Instrument Division, Gould Inc., Cleveland, $\mathrm{OH}$ ). After an abdominal incision, the left kidney was exposed and denervated by stripping all the visible renal nerves and coating the renal artery with a $10 \%$ solution of phenol in ethanol. The remaining adrenal gland was then removed and the ureter cannulated for urine collection. Two adjustable silastic balloon cuffs were placed around the aorta, one above the renal artery between the superior mesenteric and celiac arteries, the other below the left renal artery so that the renal perfusion pressure could be fixed at different levels. Silk ligatures were placed loosely around the superior mesenteric and celiac arteries and tighten to further elevate the renal perfusion pressure. An ultrasonic flow probe (1R85) placed around the left renal artery allowed to continuously record the renal blood flow using a transonic transit-time flowmeter (Model T106; Transonic Systems Inc., Ithaca, NY). After a priming dose $(250 \mathrm{mg} / \mathrm{kg}$, i.v. $)$ of polyfructosan (Inutest, Laevosan, Linz, Austria), a hormone-cocktail (3) designed to fix the circulating levels of the most important sodiumand water-retaining hormones was infused at a rate of $330 \mu \mathrm{l} / \mathrm{kg}$ per min (Pump Model 2400-001; Harvard Apparatus, South Natick, MA). It contained D-aldosterone ( $66 \mathrm{ng} / \mathrm{kg}$ per min), hydrocortisone ( $33 \mathrm{ng} /$ $\mathrm{kg}$ per $\mathrm{min}$ ), norepinephrine ( $333 \mathrm{ng} / \mathrm{kg}$ per $\mathrm{min}$ ) and $\mathrm{Arg}^{8}$-vasopressin

1. Abbreviations used in this paper: ACE, angiotensin converting enzyme; AT1 and AT2 receptors, subtypes 1 and 2 of angiotensin II receptors. 

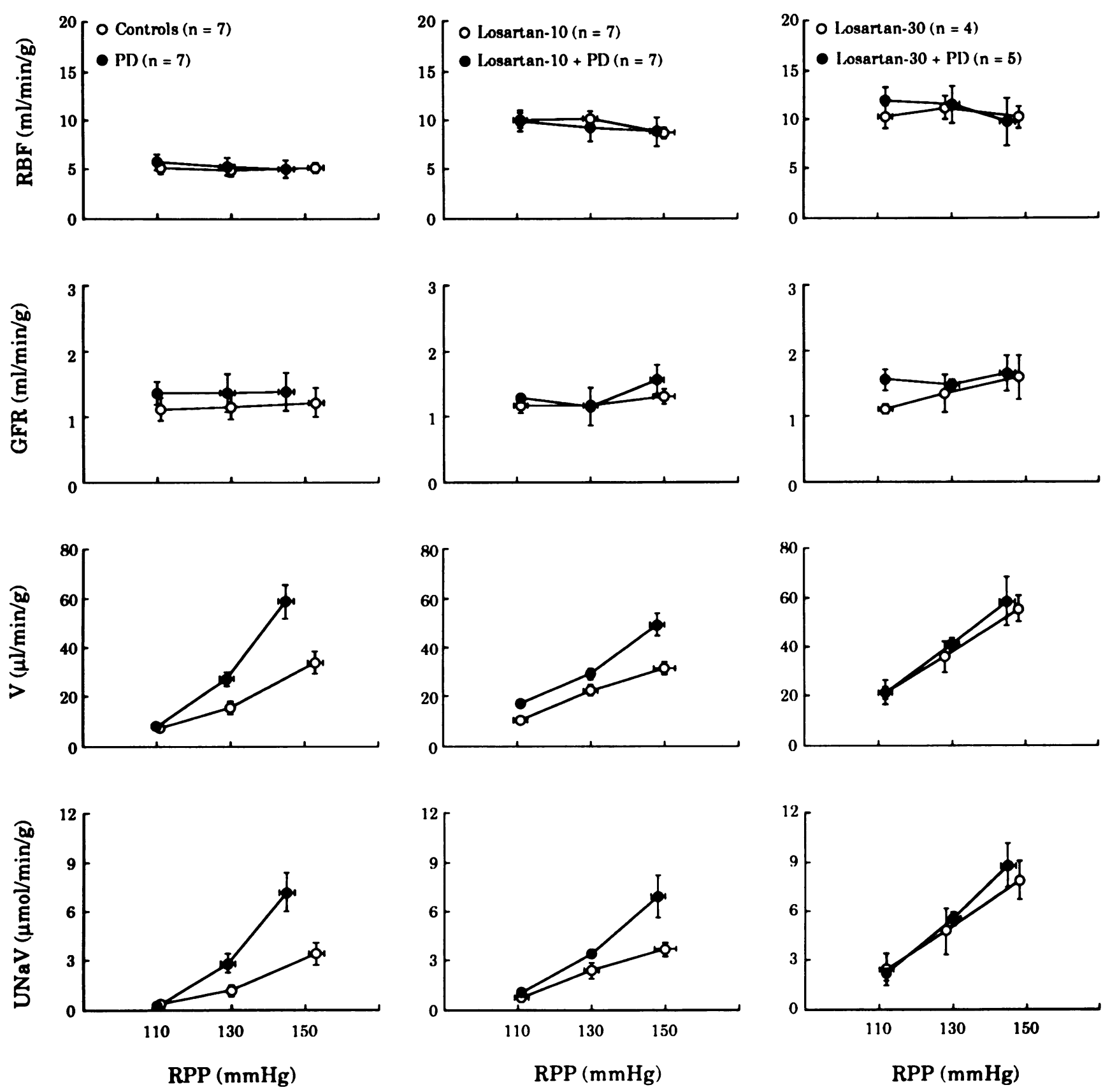

Figure 1. Effects of $\mathrm{AT}_{2}$ and combined $\mathrm{AT}_{1}$ and $\mathrm{AT}_{2}$ receptor blockade on the relationships between renal perfusion pressure (RPP), renal blood flow $(R B F)$, glomerular filtration rate $(G F R)$, urine flow $(V)$, and natriuresis ( $U N a V)$ in rats with fixed plasma concentrations of angiotensin II. (A) Controls and PD 123319 (PD, $50 \mu \mathrm{g} / \mathrm{kg}$ per min i.v.). (B) Losartan, $10 \mathrm{mg} / \mathrm{kg}$ i.v. given alone (Losartan-10) or with PD 123319 $($ Losartan-10 $+P D)$. (C) Losartan, $30 \mathrm{mg} / \mathrm{kg}$ i.v. given alone (Losartan-30) or with PD 123319 (Losartan-30 + PD).

acetate $(0.17 \mathrm{ng} / \mathrm{kg}$ per min $)$. Drugs were obtained from Sigma Chemicals Co. (St. Louis, MO) and dissolved in $0.9 \%$ sodium chloride containing $1 \%$ bovine serum albumin (Fraction V; Sigma Chemicals Co.) and $1.25 \%$ polyfructosan. At the end of the experiment, the kidney was decapsulated, removed, cut in half, blotted dry and weighed.

Renal function parameters. Renal perfusion pressure $(\mathrm{mmHg})$ was estimated as the femoral artery pressure when the suprarenal aortic cuff was inflated and as the carotid artery pressure when the infrarenal aortic cuff was inflated. Glomerular filtration rate $(\mathrm{ml} / \mathrm{min}$ per $\mathrm{g})$ was measured by polyfructosan clearance. Urine flow ( $\mu \mathrm{l} / \mathrm{min}$ per $\mathrm{g}$ ) was determined by weighing, and sodium concentration measured by flame pho- tometry (IL meter, model 243; Lexington, MA) so as to calculate the urinary sodium excretion ( $\mu \mathrm{mol} / \mathrm{min}$ per $\mathrm{g}$ ). All the renal function parameters were normalized per gram of the left kidney weight.

Experimental protocols. In the first protocol, the circulating levels of angiotensin II were maintained stable by an intravenous injection of quinapril ( $10 \mathrm{mg} / \mathrm{kg}$, i.v.), an angiotensin converting enzyme (ACE) ${ }^{1}$ inhibitor (Parke-Davis, Ann Arbor, MI) given $35 \mathrm{~min}$ before the start of the study followed by an intravenous infusion of angiotensin II ( $30 \mathrm{ng} / \mathrm{kg} /$ min, i.v.). PD 123319 (Parke-Davis, Ann Arbor, MI), a specific $\mathrm{AT}_{2}$ receptor antagonist $\left(\mathrm{IC}_{50}\right.$ of $2 \times 10^{-8} \mathrm{M}$ and above $1 \times 10^{-4} \mathrm{M}$ for $\mathrm{AT}_{2}$ and $\mathrm{AT}_{1}$ receptors respectively) (17) was infused at the dose of 50 

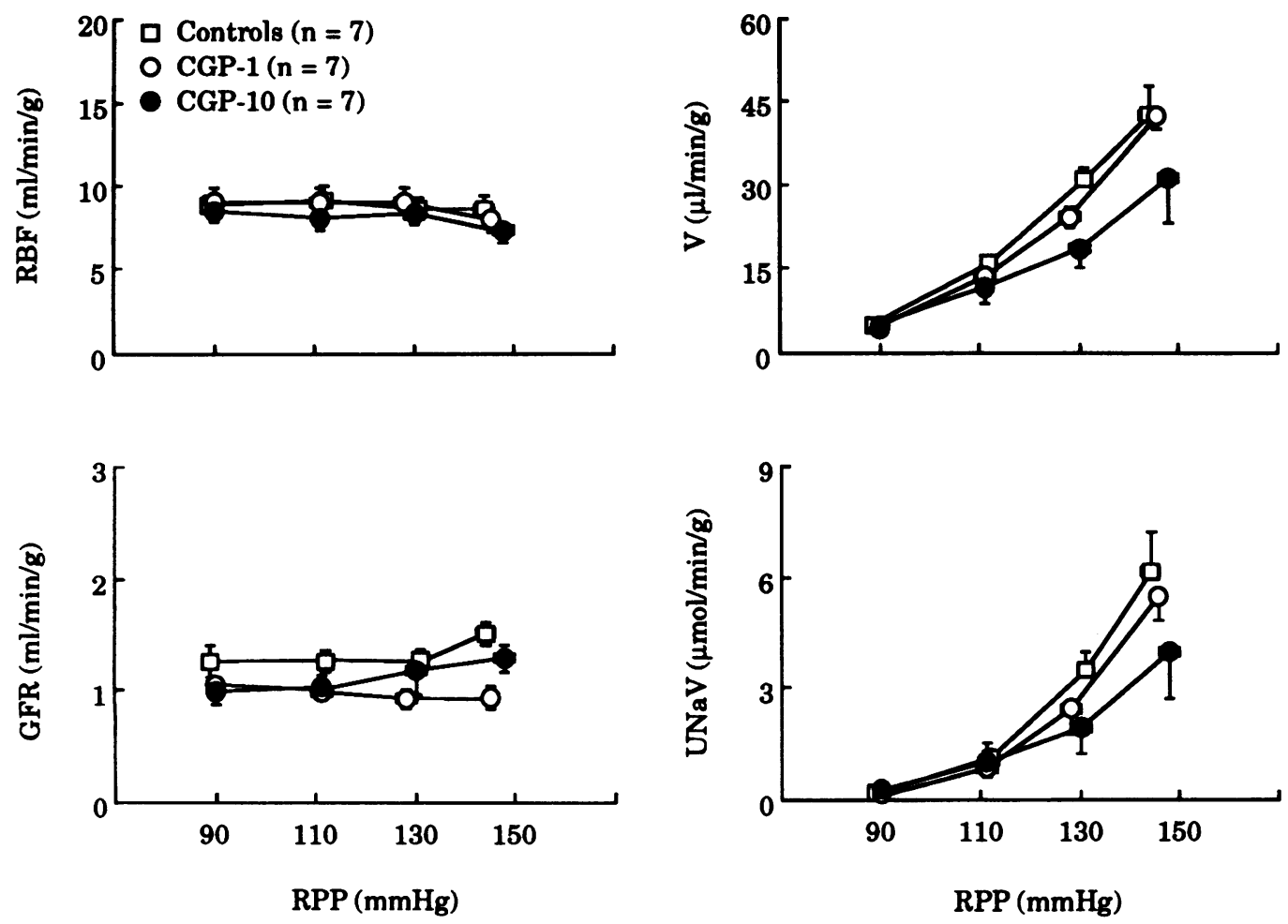

Figure 2. Effects of CGP 42112B on the relationships between renal perfusion pressure ( $R P P)$, renal blood flow ( $R B F)$, glomerular filtration rate $(G F R)$, urine flow $(V)$ and natriuresis $(U N a V)$ in rats deprived of endogenous angiotensin II (Controls). CGP 42112B was given i.v. at the doses of $1(C G P-1)$ or $10(C G P-10) \mu \mathrm{g} / \mathrm{kg} \mathrm{per} / \mathrm{min}$.

$\mu \mathrm{g} / \mathrm{kg}$ per min which, according to Macari et al. (18), yielded plasma concentrations near $3 \times 10^{-6} \mathrm{M}$, i.e., a value which remains highly specific for $\mathrm{AT}_{2}$ receptors. However, to further exclude any effect of PD 123319 on $\mathrm{AT}_{1}$ receptors, the experiment was repeated in rats having received a single intravenous injection of losartan (Du Pont Merck Pharmaceutical Co., Wilmington, $\mathrm{DE}$ ), a long-acting antagonist of $\mathrm{AT}_{1}$ receptors $\left(\mathrm{IC}_{50}\right.$ of $3 \times 10^{-4}$ and $7 \times 10^{-9} \mathrm{M}$ for $\mathrm{AT}_{2}$ and $\mathrm{AT}_{1}$ receptors, respectively). Losartan was given 30 minutes prior to the experiment, either at a usual $(10 \mathrm{mg} / \mathrm{kg})$ or a high $(30 \mathrm{mg} / \mathrm{kg})$ dose, which led to plasma concentrations near $6 \times 10^{-5}$ and $3 \times 10^{-4} \mathrm{M}$ respectively (18). In the second protocol, the effects of CGP 42112B (Ciba-Geigy Ltd, Basel, Switzerland), a specific $\mathrm{AT}_{2}$ receptor ligand $\left(\mathrm{IC}_{50}\right.$ of $5 \times 10^{-10}$ and $2 \times 10^{-6} \mathrm{M}$ for $\mathrm{AT}_{2}$ and $\mathrm{AT}_{1}$ receptors respectively) which exhibits agonistic properties (10) were studied in a preparation deprived of endogenous angiotensin II by an intravenous injection of quinapril $(10 \mathrm{mg} / \mathrm{kg}$, i.v.). Two different doses ( 1 and $10 \mu \mathrm{g} / \mathrm{kg}$ per min, i.v.) of CGP 42112B were used, which yielded plasma concentrations of $1 \times 10^{-8}$ and $4 \times$ $10^{-8} \mathrm{M}$, respectively (18). Both studies were conducted in agreement with our institutional guidelines for animal care.

Statistical analysis. Values are mean \pm standard error. One-way ANOVA was used to assess the effects of renal perfusion pressure within groups, and two-way ANOVA for between-group comparisons.

\section{Results}

As shown in Column A of the Fig. 1, in control conditions, an increase in the renal perfusion pressure from 110 to $150 \mathrm{mmHg}$, did not change the renal blood flow and glomerular filtration rate but induced an eightfold increase in the natriuresis. The infusion of PD 123319 did not change the renal blood flow and glomerular filtration rate, while it significantly $(P<0.001)$ increased urine flow and natriuresis, especially at the two highest renal perfusion pressure levels. Column B shows that, when compared to controls, the $10 \mathrm{mg} / \mathrm{kg}$ dose of losartan almost doubled the renal blood flow while it did not affect significantly the glomerular filtration rate as well as the relationships between pressure, urine flow and natriuresis. When PD 123319 was added to losartan, renal blood flow and glomerular filtration rate remained unchanged while urine flow $(P<0.001)$ and natriuresis $(P<0.01)$ significantly increased. As shown in Column C, a $30 \mathrm{mg} / \mathrm{kg}$ dose of losartan did not elevate renal blood flow more than the $10 \mathrm{mg} / \mathrm{kg}$ dose but, in addition, significantly enhanced the pressure-natriuresis. When PD 123319 was added to this dose of losartan it was devoid of effects.

As CGP 42112B exhibits agonistic properties, its effects were studied in rats deprived of endogenous angiotensin II. Fig. 2 shows that in control animals, a stepwise increase in renal perfusion pressure did not change renal blood flow and glomerular filtration rate, but increased urine flow and natriuresis to a similar extent as that observed in the first experiments after infusion of PD 123319. In this preparation, CGP 42112B did not modify the renal blood flow and glomerular filtration rate, but dosedependently decreased urine flow and natriuresis. These changes reached statistical significance $(P<0.01$ and $P<0.05$ for urine flow and natriuresis respectively) with the $10 \mu \mathrm{g} / \mathrm{kg}$ per min dose.

\section{Discussion}

The present work demonstrates that in rats receiving a normal sodium diet, acute stimulation of renal $\mathrm{AT}_{2}$ receptors has no effect on total renal blood flow but blunts the pressure-diuresis and natriuresis. Previous attempts to disclose a function for these receptors suggested that $\mathrm{AT}_{2}$ antagonists could elevate the urine volume, chloride and bicarbonate excretion in anesthetized rats (19) or increase free water formation in anesthetized dogs (20). However, the specificity of these observations was questioned $(18,21)$ as the doses of the compounds used to 
block the $\mathrm{AT}_{2}$ receptors were high enough to non-specifically interact with $\mathrm{AT}_{1}$ receptors. In the present work, the doses of antagonists and agonist used were maintained low enough to remain highly specific for $\mathrm{AT}_{2}$ receptors. In these conditions, $\mathrm{AT}_{2}$ receptor stimulation or blockade dose-dependently reduced or enhanced the pressure-natriuresis. This effect persisted after administration of 10 but not of $30 \mathrm{mg} / \mathrm{kg}$ of losartan, a difference which is likely to be due to a non-specific blockade of $\mathrm{AT}_{2}$ receptors by the high dose of losartan since: (a) the maximal vasodilation and thus the complete $\mathrm{AT}_{1}$ blockade was already obtained with the $10 \mathrm{mg} / \mathrm{kg}$ dose, and (b) according to Macari et al. (18), the plasma concentration of losartan following the $30 \mathrm{mg} / \mathrm{kg}$ dose might reach the IC50 of this drug for rabbit uterus $\mathrm{AT}_{2}$ receptors.

Such an observation is in good agreement with two recent reports showing that losartan given either acutely (22) or chronically (23) does not affect the pressure-natriuresis or the renal adaptation to a low sodium diet in rats. Since this lack of effect of losartan is in contrast with the natriuretic properties of ACE inhibitors $(23,24)$, it supports a role for $\mathrm{AT}_{2}$ receptors as promoters of sodium reabsorption as ACE inhibitors which suppress angiotensin II formation, suppress also the stimulation of both $\mathrm{AT}_{1}$ and $\mathrm{AT}_{2}$ receptors.

In addition, it is noteworthy that the effects of both the antagonist (PD 123319) and the ligand with agonistic properties (CGP 42112B) were more marked when the renal perfusion pressure was elevated than when it remained near baseline. This suggests that part of the failure of previous attempts to disclose a function for renal $\mathrm{AT}_{2}$ receptors could have been due to the fact that, in these experiments, renal perfusion pressure was either normal or uncontrolled. The observation that $\mathrm{AT}_{2}$ receptors were found more efficient at high than at normal pressure indicates that they may directly interact with the mechanisms involved in the pressure-natriuresis. Despite extensive work, these mechanisms are not fully understood. The two major current hypothesis rely upon a blood pressure-dependent increase in renal interstitial pressure (25) or in the medullary blood flow (26). Therefore the location and the site (tubular or vascular) of action of $\mathrm{AT}_{2}$ receptors remains to be determined. However, as far as the present data can fully be extrapolated to physiological conditions, it can be speculated that besides the role of $\mathrm{AT}_{1}$ receptors, angiotensin II through $\mathrm{AT}_{2}$ receptors stimulation is able to prevent the sodium losses which otherwise would accompany any acute increase in blood pressure. In addition, since an abnormal pressure-natriuresis is the hallmark of any form of chronic hypertension (5), an enhanced role of $\mathrm{AT}_{2}$ receptors could well be involved in the development and/or the maintenance of hypertension.

In conclusion, it appears that, in rats fed a normal sodium diet, $\mathrm{AT}_{2}$ receptor stimulation acutely blunts the diuretic and natriuretic responses to blood pressure increases. This effect is likely to contribute to the role of the renin-angiotensin system in body fluid and blood pressure regulation.

\section{Acknowledgments}

Drs. D. J. Taylor and F. Taillard (Parke-Davis Laboratory) kindly provided us with PD 123319 and quinapril. Losartan was a gift of Drs. O. Madonna and M. Fouchard (Merk Sharp \& Dohme Chibret Company) and CGP 42112B of Dr. M. De Gasparo (Ciba-Geigy Laboratory). We are greatly indebted to Drs. J. Ménard, C. Julien and B. Waeber for their help and comments.

\section{References}

1. Navar, L. G., and L. Rosivall. 1984. Contribution of the renin-angiotensin system to the control of intrarenal hemodynamics. Kidney Int. 25:857-868.

2. Navar, L. G., P. K. Carmines, W. C. Huang, and K. D. Mitchell. 1987. The tubular effects of angiotensin II. Kidney Int. 31 (Suppl 20):S-81-S-88.

3. Mattson, D. L., H. Raff, and R. J. Roman. 1991. Influence of angiotensin II on pressure natriuresis and renal hemodynamics in volume-expanded rats. Am. J. Physiol. 260:R1200-1209.

4. Van der Mark, J., and R. L. Kline. 1994. Altered pressure natriuresis in chronic angiotensin II hypertension in rats. Am. J. Physiol. 266:R739-R748.

5. Guyton, A. C. 1990. Long-term arterial pressure control: an analysis from animal experiments and computer and graphic models. Am. J. Physiol. 259:R865R877.

6. Bumpus, F. M., K. J. Catt, A. T. Chiu, M. De Gasparo, T. Goodfriend, A. Husain, M. J. Peach, D. J. Taylor, Jr., and P. B. M. W. M. Timmermans. 1991. Nomenclature for angiotensin receptors. Hypertension. 17:720-721.

7. Murphy, T. J., R. W. Alexander, K. K. Griendling, M. S. Runge, and K. E. Bernstein. 1991. Isolation of a cDNA encoding the vascular type-1 angiotensin II receptor. Nature (Lond.). 351:233-236.

8. Sasaki, K., Y. Yamano, S. Bardhan, N. Iwai, J. J. Murray, M. Hasegawa, Y. Matsuda, and T. Inagami. 1991. Cloning and expression of a complementary DNA encoding a bovine adrenal angiotensin II type-1 receptor. Nature (Lond.). 351:230-232.

9. Mukoyama, M., M. Nakajima, M. Horiuchi, H. Sasamura, R. E. Pratt, and V. J. Dzau. 1993. Expression cloning of type 2 angiotensin II receptor reveals a unique class of seven-transmembrane receptors. J. Biol. Chem. 268:24539-24542.

10. Kambayashi, Y., S. Bardhan, K. Takahashi, S. Tsuzuki, H. Inui, T. Hamakubo, and T. Inagami. 1993. Molecular cloning of a novel angiotensin II receptor isoform involved in phosphotyrosine phosphatase inhibition. J. Biol. Chem. 268:24543-24546.

11. Zhuo, J., K. Song, P. J. Harris, and F. A. O. Mendelsohn. 1992. In vitro autoradiography reveals predominantly $\mathrm{AT}_{1}$ angiotensin II receptors in rat kidney. Renal Physiol. Biochem. 15:231-239.

12. Zhuo, J., D. Alcorn, P. J. Harris, and F. A. O. Mendelsohn. 1993. Localization and properties of angiotensin II receptors in rat kidney. Kidney Int. 44 (Suppl 42):S-40-S-46.

13. Wong, P. C., S. D. Hart, A. M. Zaspel, A. T. Chiu, R. J. Ardecky, R. D. Smith, and P. B. M. W. M. Timmermans. 1990. Functional studies of nonpeptide angiotensin II receptor subtype-specific ligands: Dup 753 (AII-1) and PD 123177 (AII-2). J. Pharmacol. Exp. Ther. 255:584-592.

14. Xie, M. H., F. Y. Liu, P. C. Wong, P. B. M. W. M. Timmermans, and M. G. Cogan. 1990. Proximal nephron and renal effects of Dup 753, a nonpeptide angiotensin II receptor antagonist. Kidney Int. 38:473-479.

15. Brasch, H., L. Sieroslawski, and P. Dominiak. 1993. Angiotensin II increases norepinephrine release from atria by acting on angiotensin subtype 1 receptors. Hypertension. 22:699-704.

16. Roman, R. J., and A. W. Cowley, Jr. 1985. Characterization of a new model for the study of pressure-natriuresis in the rat. Am. J. Physiol. 248:F190F198.

17. Dudley, D. T., R. L. Panek, T. C. Major, G. H. Lu, R. F. Bruns, B. A. Klinkefus, J. C. Hodges, and R. E. Weishaar. 1990. Subclasses of angiotensin II binding sites and their functional significance. Mol. Pharmacol. 38:370-377.

18. Macari, D., S. Bottari, S. Whitebread, M. De Gasparo, and N. Levens. 1993. Renal actions of the selective angiotensin $A T_{2}$ receptor ligands CGP 42112B and PD 123319 in the sodium-depleted rat. Eur. J. Pharmacol. 249:85-93.

19. Cogan, M. G., F. Y. Liu, P. C. Wong, and P. B. M. W. M. Timmermans. 1991. Comparison of inhibitory potency by nonpeptide angiotensin II receptor antagonists PD 123177 and Dup 753 on proximal nephron and renal transport. $J$. Pharmacol. Exp. Ther. 259:687-691.

20. Keiser, J. A., F. A. Bjork, J. C. Hodges, and D. G. Taylor, Jr. 1992. Renal hemodynamic and excretory responses to PD 123319 and losartan, nonpeptide $\mathrm{AT}_{1}$ and $\mathrm{AT}_{2}$ subtype-specific angiotensin II ligands. J. Pharmacol. Exp. Ther. 262:1154-1160.

21. Clark, K. L., M. J. Robertson, and G. Michael Drew. 1993. Role of angiotensin $\mathrm{AT}_{1}$ and $\mathrm{AT}_{2}$ receptors in mediating the renal effects of angiotensin II in the anaesthetized dog. Br. J. Pharmacol. 109:148-156.

22. Kline, R. L., and F. Liu. 1994. Modification of pressure natriuresis by long-term losartan in spontaneously hypertensive rats. Hypertension. 24:467-473.

23. Jover, B., D. Saladini, N. Nafrialdi, M. Dupont, and A. Mimran. 1994. Effect of losartan and enalapril on renal adaptation to sodium restriction in rat. Am. J. Physiol. 267:F281-F288.

24. Lu, S., D. L. Mattson, and A. W. Cowley, Jr. 1994. Renal medullary captopril delivery lowers blood pressure in spontaneously hypertensive rats. $\mathrm{Hy}$ pertension. 23:337-345.

25. Granger, J. P. 1992. Pressure natriuresis: role of renal interstitial hydrostatic pressure. Hypertension. 19 (Suppl I):I-9-I-17.

26. Fenoy, F. J., and R. J. Roman. 1991. Effect of volume expansion on papillary blood flow and sodium excretion. Am. J. Physiol. 260:F813-F822. 